\title{
Influence of Weed Management Practices on Weeds, Yield and Economics of Fingermillet (Eleusine coracana L. Gaertn)
}

\author{
S. Kujur*, V. K. Singh, D. K. Gupta, A. Tandon, V. Ekka and H. P. Agrawal
}

Dept. of Agronomy, Indira Gandhi Krishi Vishwavidyalaya, Raipur, C.G. (492 012), India

\section{Corresponding Author}

S. Kujur

e-mail: sangeetakujur431@gmail.com

\author{
Article History \\ Article ID: 3 C0641 \\ Received in $26^{\text {th }}$ October, 2017 \\ Received in revised form $29^{\text {th }}$ December, 2017 \\ Accepted in final form $19^{\text {th }}$ March, 2018
}

\begin{abstract}
A Field experiment was conducted at I.G.K.V., Rajmohini Devi College of Agricultural and Research Station, Ambikapur (C.G), during kharif 2015. The experiment was laid out in Randomized Complete Block Design (RCBD) with ten treatments, replicated thrice. Observations were taken on weed, plant growth and yield attributes, yield, and economic parameters. Panicum maxima, Elusine indica, Cyperus spp., Cynodon dactylon, Celosia argentea, Alternanthera sessilis, Alternenthera triandra, Ageratum conyzoides were found to be domimant weeds. All weed control treatments significantly reduced the weed density and dry weight of weed resulting significant increase in yield of fingermillet over weedy check. Among the weed management practices, significantly lowest density, dry matter of weeds, higher weed control efficiency and low weed index were recorded under hoeing twice by wheel hoe between rows and intra-row manual weeding followed by hand weeding twice. The maximum grain yield (32.58 and $\left.29.23 \mathrm{q} \mathrm{ha}^{-1}\right)$, straw yield ( 94.05 and $\left.84.98 \mathrm{q} \mathrm{ha}^{-1}\right)$, gross return $(62973$ and $56594 ₹$ ha $^{-1}$ ), net return (42024 and $32495 ₹^{-1}$ ha ) and B:C ratio (2.01 and 1.35) were also recorded under hoeing twice by wheel hoe between rows and intra-row manual weeding followed by two hand weeding at 20 and 40 DAS. Among herbicidal treatment, application of isoproturon @ 0.5 pre emergence+2, 4-D Na salt @ $0.5 \mathrm{~kg} \mathrm{ha}^{-1}$ post emergence appeared to be effective, economically viable for weed control, higher grain yield and net return.
\end{abstract}

Keywords: Fingermillet, weed management, yield, economics

\section{Introduction}

Fingermillet (Eleusine coracana L.) is an important small millet crop grown in India. Among the millets it ranks third in the country in both area (1.14 $\mathrm{mha})$ and production (1.82 $\mathrm{mt}$ ) after sorghum and pearlmillet. Major states where finger millet is grown are Karnataka, Andhra Pradesh, Jharkhand and Chhattisgarh. In Chhattisgarh fingermillet is grown in an area of 6.9 thousand ha with production of 1.3 thousand tonne and having a productivity of $188 \mathrm{~kg} \mathrm{ha}^{-1}$ (Anonymous, 2016).

Fingermillet also known as ragi, african millet and mandua, valued as staple food and first important crop among small millets. It contains $9.2 \%$ protein, $1.29 \%$ fat, $76.32 \%$ carbohydrate, $2.24 \%$ minerals and $3.9 \%$ ash besides vitamin $A$ and $B$. The grains are rich in phosphorus, potassium and amino acid (methionine). It is also rich source of calcium (410 mg $100 \mathrm{~g}^{-1}$ grain) for growing children and aged people (Tomar et al., 2011). Millets have hypoglycemic effect, which is attributed to high fibre content. High fibre diets containing complex carbohydrates are slowly digested and absorbed thus bring reduction in postprandial glucose. It is good for persons suffering from diabetes because of very slow release of glucose into blood. Further the straw forms a nutritious fodder for livestock. In northern hills, grains are eaten mostly in the form of 'Chapaties' and in south India grains are used in many preparations like cakes, puddings, sweets, etc. Germinating grains are malted and fed to infants also. It is also good for pregnant women.

Weeds are considered as one of the major problems the farmer is faced with in the production of crop. Fingermillet has very poor competitive ability with weeds due to its initial slow growth. Initial growth period of fingermillet is subjected to heavy weed infestation resulting into higher competition and drastic reduction in yield (Pradhan et al., 2012; Patil et al., 2013). Since single method is not able to control all weeds up to desired level, integration of weed management practices can be an effective weed control strategy to achieve greater weed control efficiency and increase overall benefit of fingermillet cultivation. In this context present investigation is carried out to evaluate the efficient weed management practices under fingermillet.

\section{Materials and Methods}

The field experiment was conducted at I.G.K.V., Rajmohini Devi College of Agricultural and Research Station, Ambikapur 
during kharif season 2015. The treatments comprised of different weed management practices viz., $T_{1}-$ Weedy check (control), $\mathrm{T}_{2}$ - Hand weeding twice, $\mathrm{T}_{3}$ - Hoeing twice by wheel hoe between rows and intra-row manual weeding, $\mathrm{T}_{4}$ - Isoproturon, $\mathrm{T}_{5}-2$,4-D Na salt, $\mathrm{T}_{6}$ - Isoproturon+2,4-D Na salt, $\mathrm{T}_{7}$ - Oxyfluorfen, $\mathrm{T}_{8}$ - Oxyfluorfen $+1 \mathrm{HW}, \mathrm{T}_{9}$-Oxadiragyl and $\mathrm{T}_{10}$ - Oxadiargyl $+1 \mathrm{HW}$. The experimental trial was laid out in Randomized Block Design with three replications. The soil of experimental field was sandy loam with $\mathrm{pH} 5.82$, medium in available $\mathrm{N}\left(226 \mathrm{~kg} \mathrm{ha}^{-1}\right)$ and $\mathrm{P}\left(10 \mathrm{~kg} \mathrm{ha}^{-1}\right)$ and high in available $\mathrm{K}\left(288 \mathrm{~kg} \mathrm{ha}^{-1}\right)$, respectively. Fingermillet variety 'Indira Ragi-1' was sown in July 20, 2015 in $22.5 \mathrm{~cm}$ wide rows using seed rate @ $8 \mathrm{~kg} \mathrm{ha}^{-1}$. The recommended dose of fertilizer 80: 40: $20 \mathrm{~kg}$ ha-1 N, $\mathrm{P}_{2} \mathrm{O}_{5}$ and $\mathrm{K}_{2} \mathrm{O}$ was applied as half of $\mathrm{N}$ and full $\mathrm{P}_{2} \mathrm{O}_{5}$ and $\mathrm{K}_{2} \mathrm{O}$ at the time of sowing and remaining nitrogen in two equal splits at active tillering and panicle initiation stages. The crop was raised with all the recommended package of practices crop was harvested on November 29, 2015. Herbicides were applied by using knapsack sprayer at the spray volume of 700 lit ha ${ }^{-1}$ of water.

Weed density (no. $\mathrm{m}^{-2}$ ) and dry weight of weeds $\left(\mathrm{g} \mathrm{m}^{-2}\right.$ ) were recorded by putting quadrate of $0.25 \mathrm{~m}^{2}$ at three random spots in each plot. The data on weed count and weed biomass were subjected to square root transformation before carrying out analysis of variance and comparisons were made on transformed value. Weed flora composition of each species was calculated with the help of the following formula:

Weed flora composition=(Density of a weed sp.in a community / Density of all weed species in a community) $\times 100$

The weed control efficiency and weed index was calculated by following formula suggested by Mani et al. (1973) and Gill and Vijayakumar (1966), respectively.

WCE $=\{(D W C-D W T) / D W C\} \times 100$

Where,

WCE $=$ Weed control efficiency $(\%)$

DWC $=$ Dry weight of weeds in weedy check plot (g)

DWT $=$ Dry weight of weeds in treated plot $(\mathrm{g})$

$\mathrm{WI}=\{(\mathrm{X}-\mathrm{Y}) / \mathrm{X}\} \times 100$

Where,

$\mathrm{WI}=$ Weed Index $(\%)$

$X=$ Yield obtained in the weed free plot $\left(q \mathrm{ha}^{-1}\right)$

$\mathrm{Y}=$ Yield obtained in the respective treated plot $\left(\mathrm{q} \mathrm{ha} \mathrm{h}^{-1}\right)$

Data on grain yield of finger millet was recorded per plot and converted into $q$ ha $^{-1}$. The cost of cultivation, gross return, net returns and benefit: cost ratio ( $\mathrm{B}$ : $\mathrm{C}$ ratio) were calculated by using prevailing prices of input and output.

\section{Results and Discussion}

The findings of the present study as well as relevant discussion have been presented under following heads:

\subsection{Weed flora}

The dominant weed flora associated with experimental field were: Panicum maxima, Elusine indica, Cyperus spp., Cynodon dactylon among monocots. Dicot weeds dominated by Alternanthera triandra, Alternanthera sessilis, Ageratum conyzoides and Celosia argentea. The relative density under weedy check of monocot weeds $(38.88 \%)$ was less than that of dicot weeds (46.75\%). The maximum relative weed density was recorded from Alternanthera triandra which was the most dominant weed species that contributing $24.53 \%$ of the total weed population (Table 1).

Table 1: Weed species and their relative density (\%) under weedy check recorded in the experiment field

\begin{tabular}{|c|c|c|c|c|}
\hline $\begin{array}{l}\text { SI. } \\
\text { No. }\end{array}$ & Weed species & Family & $\begin{array}{l}\text { Vernacu- } \\
\text { lar Name }\end{array}$ & $\begin{array}{c}\text { Weed flora in } \\
\text { weedy check } \\
\text { at harvest }\end{array}$ \\
\hline A. & Monocot & & & \\
\hline 1. & $\begin{array}{l}\text { Panicum } \\
\text { maxima }\end{array}$ & Poaceae & $\begin{array}{l}\text { Guinea } \\
\text { grass }\end{array}$ & $18.67(19.45)$ \\
\hline 2. & $\begin{array}{l}\text { Elusine indica } \\
\text { (L.) Gaertn }\end{array}$ & Poaceae & $\begin{array}{l}\text { Jungali } \\
\text { kodo }\end{array}$ & $4.44(4.63)$ \\
\hline 3. & Cyperus spp. & $\begin{array}{l}\text { Cypera- } \\
\text { ceae }\end{array}$ & Motha & $4.44(4.63)$ \\
\hline \multirow[t]{2}{*}{4.} & $\begin{array}{l}\text { Cynodon dac- } \\
\text { tylon (L.) Pers. }\end{array}$ & Poaceae & Doob & 7.78 (10.19) \\
\hline & Total & & & 37.33 (38.88) \\
\hline B. & Dicot & & & \\
\hline 5. & $\begin{array}{l}\text { Celosia argen- } \\
\text { tea } \mathrm{L} \text {. }\end{array}$ & $\begin{array}{l}\text { Amaran- } \\
\text { thaceae }\end{array}$ & Silyari & $4.44(4.63)$ \\
\hline 6. & $\begin{array}{l}\text { Alternanthera } \\
\text { sessilis (L.) } \\
\text { R.Br.ex Roem. } \\
\text { \& Schult }\end{array}$ & $\begin{array}{l}\text { Amaran- } \\
\text { thaceae }\end{array}$ & $\begin{array}{l}\text { Garundi } \\
\text { ark }\end{array}$ & $8.45(8.80)$ \\
\hline 7. & $\begin{array}{l}\text { Alternanthera } \\
\text { triandra }\end{array}$ & $\begin{array}{l}\text { Amaran- } \\
\text { thaceae }\end{array}$ & & 23.55 (24.53) \\
\hline \multirow[t]{4}{*}{8.} & $\begin{array}{l}\text { Azeratum } \\
\text { conyzoides } \\
\text { (L.) }\end{array}$ & $\begin{array}{l}\text { Astera- } \\
\text { ceae }\end{array}$ & $\begin{array}{l}\text { Mahak- } \\
\text { wa }\end{array}$ & 8.44 (8.79) \\
\hline & Total & & & $44.88(46.75)$ \\
\hline & Others & & & $13.78(14.35)$ \\
\hline & Total & & & 96.00 \\
\hline
\end{tabular}

Figure in parenthesis indicates relative density (\%)

\subsection{Weed density and weed dry biomass}

Weed control treatments had significant effect on total weed population. At harvest, the minimum population and dry weight (11.55 plants $\mathrm{m}^{-2}$ and $1.08 \mathrm{~g} \mathrm{~m}^{-2}$ ) was recorded under hoeing twice by wheel hoe between rows and intrarow manual weeding and closely followed by hand weeding twice (12.44 plants $\mathrm{m}^{-2}$ and $1.67 \mathrm{~g} \mathrm{~m}^{-2}$ ), obviously due to 
direct removal of existing weed at 20 and 40 DAS. Among the herbicides isoproturon @ 0.5 pre emergence+2,4-D Na salt @ $0.5 \mathrm{~kg} \mathrm{ha}^{-1}$ post emergence, had given that best result and significantly lower weed population (43.10 plants $\mathrm{m}^{-2}$ ) and dry matter accumulation of weeds $\left(65.82 \mathrm{~g} \mathrm{~m}^{-2}\right)$ as compare to or other chemical treatments which was at par with mechanical weeding (Table 2). It might be due to the lowest population of grassy and non grassy weeds in this treatment. Similar observations were recorded by Ramesh and Nadanssababady (2005), Sinha and Singh (2005), Rahaman and Mukherjee (2009) and Hawaldar and Agasimani (2012). Highest weed density (96.00 plants $\mathrm{m}^{-2}$ ) and weed dry weight (154.47 g $\mathrm{m}^{-2}$ ) recorded in unweeded check. Similar finding were also reported by Malik et al. (1988) and Dhanapal et al. (2015).

\subsection{Weed control efficiency and weed index}

Effect of weed management practices on weed control efficiency was significant. Highest weed control efficiency (99.30\%) was recorded in hoeing twice by wheel hoe between rows and intra-row manual weeding followed by hand weeding twice at 20 and 40 DAS $(98.92 \%)$. This may be due to complete removal of weeds at 20 and 40 DAS causes lower weed population as well as dry matter accumulation of weeds in these treatments. This result is also similar with the findings of Kashid et al. (2015). Among the herbicidal treatment, oxyfluorfen @ $0.075 \mathrm{~kg} \mathrm{ha}^{-1}$ and oxadiargyl $0.5 \mathrm{~kg}$ $\mathrm{ha}^{-1}$ supplemented with one hand weeding at 40 DAS having maximum weed control efficiency (Table 2). Vinothini and Arthanari (2017) also reported highest weed control efficiency in pre-emergence application of herbicide+hand weeding at

Table 2: Influences of weed management practices on weed density, weed dry weight, weed control efficiency (WCE) and weed index of fingermillet

\begin{tabular}{|c|c|c|c|c|c|c|}
\hline Treatment & $\begin{array}{c}\text { Dose } \\
\left(\mathrm{kg} \mathrm{ha}^{-1}\right)\end{array}$ & $\begin{array}{l}\text { Time of } \\
\text { application }\end{array}$ & $\begin{array}{c}\text { Weed density } \\
\left(\text { No. } \mathrm{m}^{-2}\right) \text { at } \\
\text { harvest }\end{array}$ & $\begin{array}{l}\text { Weed dry weight } \\
\left(\mathrm{g} \mathrm{m}^{-2}\right) \text { at harvest }\end{array}$ & $\begin{array}{c}\text { WCE } \\
(\%) \text { at } \\
\text { harvest }\end{array}$ & $\begin{array}{c}\text { Weed } \\
\text { index } \\
(\%)\end{array}$ \\
\hline $\mathrm{T}_{1}:$ Weedy check (control) & - & - & $9.82(96.00)$ & 12.45 (154.47) & - & 72.22 \\
\hline $\mathrm{T}_{2}:$ Hand weeding twice & - & 20 and 40 DAS & $3.59(12.44)$ & $1.47(1.67)$ & 98.92 & 10.28 \\
\hline $\begin{array}{l}\mathrm{T}_{3} \text { : Hoeing twice by wheel hoe between } \\
\text { rows and intra-row manual weeding }\end{array}$ & & 20 and 40 DAS & 3.47 (11.55) & $1.25(1.08)$ & 99.30 & - \\
\hline $\mathrm{T}_{4}$ : Isoproturon & 0.5 & (2-3 DAS) & $6.90(47.10)$ & 9.05 (81.39) & 47.31 & 35.77 \\
\hline $\mathrm{T}_{5}: 2,4-\mathrm{D}$ Na salt & 0.5 & (25 DAS) & $7.94(62.67)$ & 10.32 (105.97) & 31.40 & 65.41 \\
\hline $\mathrm{T}_{6}$ : Isoproturon+2,4-D Na salt & $0.5+0.5$ & $\begin{array}{c}(2-3 \text { DAS })+(25 \\
\text { DAS })\end{array}$ & $6.60(43.10)$ & $8.13(65.82)$ & 57.39 & 30.83 \\
\hline $\mathrm{T}_{7}:$ Oxyfluorfen & 0.075 & (2-3 DAS) & $6.93(47.55)$ & 9.68 (93.19) & 39.67 & 58.03 \\
\hline $\mathrm{T}_{8}:$ Oxyfluorfen+1 HW & 0.075 & $\begin{array}{l}(2-3 \text { DAS })+40 \\
\text { DAS }\end{array}$ & $4.11(16.44)$ & $3.48(11.64)$ & 92.46 & 34.88 \\
\hline $\mathrm{T}_{9}:$ Oxadiragyl & 0.05 & (2-3 DAS) & $7.97(63.11)$ & $9.92(98.03)$ & 36.54 & 60.20 \\
\hline $\mathrm{T}_{10}:$ Oxadiargyl+1 HW & 0.05 & $\begin{array}{l}(2-3 \text { DAS })+40 \\
\text { DAS }\end{array}$ & $4.76(22.22)$ & 3.66 (12.92) & 91.64 & 39.22 \\
\hline $\mathrm{SEm} \pm$ & - & & 0.17 & 0.17 & - & - \\
\hline$C D(p=0.05)$ & - & - & 0.52 & 0.50 & - & - \\
\hline
\end{tabular}

40 DAS.

Weed index is a measure of yield loss caused due to varying degree of weed competition compared to the relatively weed free condition throughout the crop period leading to higher productivity. It is the ultimate parameter towards appraisal of the superiority or inferiority of weed control treatments. Maximum weed index were noticed under weedy check (72.22\%) whereas minimum weed index were registered under two hand weeding at 20 and 40 DAS (10.28\%).

\subsection{Grain yield and straw yield}

Effect of weed management practices on grain and straw yield was significant. The data (Table 3 ) showed that maximum grain yield (32.58 q ha-1) and straw yield (94.05 q ha-1) was obtained with hoeing twice by wheel hoe between rows and intra-row manual weeding followed by hand weeding (29.23 and $84.98 \mathrm{q} \mathrm{ha}^{-1}$ grain and straw yield) at 20 and 40 DAS. Higher grain yield was attributed to better control of weeds, lower weed index and higher weed control efficiency throughout the crop growth period, which resulted in better availability of growth factors like light, space, nutrients and moisture to the crop resulting in better crop growth and yield. Similar results were also reported by Singh et al. (2006) and Pradhan et al. (2010). Among the herbicidal treatments application of isoproturon @ 0.5 pre emergence+2,4-D Na salt @ 0.5 kg ha-1 post emergence produced maximum grain yield $\left(22.54 \mathrm{q} \mathrm{ha}^{-1}\right)$ and straw yield ( $\left.63.75 \mathrm{q} \mathrm{ha}^{-1}\right)$. Minimum grain and straw yield was recorded in weedy check (9.05 and $\left.26.85 \mathrm{q} \mathrm{ha}^{-1}\right)$. This 


\begin{tabular}{|c|c|c|c|c|c|c|c|c|}
\hline Treatment & $\begin{array}{l}\text { Dose } \\
(\mathrm{kg} \\
\left.\mathrm{ha}^{-1}\right)\end{array}$ & $\begin{array}{l}\text { Time of } \\
\text { application }\end{array}$ & $\begin{array}{c}\text { G r a in } \\
\text { yield } \\
(\mathrm{q} \mathrm{ha-1})\end{array}$ & $\begin{array}{l}\text { Straw } \\
\text { yield } \\
\left(q \text { ha }^{-1}\right)\end{array}$ & $\begin{array}{l}\text { Total cost } \\
\text { of } \\
\text { cultivation } \\
(₹ \text { ha-1) }\end{array}$ & $\begin{array}{l}\text { Gross } \\
\text { return } \\
\left(₹ \text { ha }^{-1}\right)\end{array}$ & $\begin{array}{l}\text { Net } \\
\text { return } \\
\left(₹ h^{-1}\right)\end{array}$ & $\begin{array}{l}\mathrm{B}: \mathrm{C} \\
\text { ratio }\end{array}$ \\
\hline $\mathrm{T}_{1}:$ Weedy check (control) & - & - & 9.05 & 26.85 & 15349 & 17603 & 2254 & 0.15 \\
\hline $\mathrm{T}_{2}:$ Hand weeding twice & - & $\begin{array}{l}20 \text { and } 40 \\
\text { DAS }\end{array}$ & 29.23 & 84.98 & 24099 & 56594 & 32495 & 1.35 \\
\hline $\begin{array}{l}\mathrm{T}_{3} \text { : Hoeing twice by wheel hoe between } \\
\text { rows and intra-row manual weeding }\end{array}$ & - & $\begin{array}{l}20 \text { and } 40 \\
\text { DAS }\end{array}$ & 32.58 & 94.05 & 20949 & 62973 & 42024 & 2.01 \\
\hline $\mathrm{T}_{4}$ : Isoproturon & 0.5 & (2-3 DAS) & 20.93 & 62.14 & 15913 & 40710 & 24797 & 1.56 \\
\hline $\mathrm{T}_{5}: 2,4-\mathrm{D} \mathrm{Na}$ salt & 0.5 & (25 DAS) & 11.27 & 32.30 & 15793 & 21747 & 5954 & 0.38 \\
\hline $\mathrm{T}_{6}$ : Isoproturon+2,4-D Na salt & $0.5+0.5$ & $\begin{array}{l}\text { (2-3 DAS)+ } \\
\text { (25 DAS) }\end{array}$ & 22.54 & 63.75 & 16357 & 43367 & 27010 & 1.65 \\
\hline $\mathrm{T}_{7}:$ Oxyfluorfen & 0.075 & (2-3 DAS) & 13.67 & 39.58 & 16305 & 26446 & 10141 & 0.62 \\
\hline $\mathrm{T}_{8}:$ Oxyfluorfen $+1 \mathrm{HW}$ & 0.075 & $\begin{array}{l}\text { (2-3 DAS)+ } \\
40 \text { DAS }\end{array}$ & 21.22 & 61.62 & 19805 & 41068 & 21263 & 1.07 \\
\hline $\mathrm{T}_{9}$ : Oxadiragyl & 0.05 & (2-3 DAS) & 12.97 & 39.23 & 16038 & 25333 & 9295 & 0.58 \\
\hline $\mathrm{T}_{10}$ : Oxadiargyl+1 HW & 0.05 & $\begin{array}{l}\text { (2-3 DAS)+ } \\
40 \text { DAS }\end{array}$ & 19.80 & 57.32 & 19538 & 38299 & 18761 & 0.96 \\
\hline SEm \pm & - & - & 0.61 & 1.46 & - & - & - & - \\
\hline $\mathrm{CD}(p=0.05)$ & - & - & 1.82 & 4.35 & - & - & - & - \\
\hline
\end{tabular}

reduction in grain yield might be due to highest competition with the finger millet throughout the crop growth period (Patil and Reddy, 2014).

\subsection{Economics}

Data in Table 3 indicated that the maximum gross return Rs. $62973 \mathrm{ha}^{-1}$, net monetary return ₹ $42024 \mathrm{ha}^{-1}$ and B:C ratio 2.01 was recorded under hoeing twice by wheel hoe between rows and intra-row manual weeding followed by two hand weeding at 20 and 40 DAS, the values were ₹ 56594, ₹ $32495 \mathrm{ha}^{-1}$ and 1.35 , respectively. It might be due to higher grain yield, better weed control and higher weed control efficiency in this treatment. Among the herbicidal treatments, isoproturon @ $0.5 \mathrm{~kg} \mathrm{ha}^{-1}$ pre emergence + 2,4-D Na salt @ 0.5 $\mathrm{kg} \mathrm{ha}^{-1}$ post emergence was found superior in terms of gross return ( $₹ 43367 \mathrm{ha}^{-1}$ ), net return ( $₹ 27010 \mathrm{ha}^{-1}$ ) and B:C ratio (1.65) followed by isoproturon @ $0.5 \mathrm{~kg} \mathrm{ha}^{-1}$ alone the values were ₹ 40710, ₹ 24797 ha $^{-1}$ and 1.56, respectively. Higher net returns and $\mathrm{B}: \mathrm{C}$ ratio with herbicide and manual weeding has also been reported by Pradhan et al. (2010).

\section{Conclusion}

Hoeing twice by wheel hoe between rows and intrarow manual weeding at 20 and 40 DAS is the best weed management practice in fingermillet to obtain greater yield and economic return with more efficient weed control. Among the herbicides, application of isoproturon $0.5 \mathrm{~kg} \mathrm{ha}^{-1}$ pre emergence+2,4-D Na salt @ $0.5 \mathrm{~kg} \mathrm{ha}^{-1}$ post emergence was found superior in terms of grain yield and economics.

\section{References}

Anonymous, 2016. Ministry of agriculture and farmers welfare, Govt. of India. (ON1394).

Dhanapal, G.N., Sanjay, M.T., Hareesh, G.R., Patil, V.B., 2015. Weed and fertility management effects on grain yield and economics of finger millet following groundnut. Indian Journal of Weed Science 47(2), 139-143.

Gill, V.S., Vijayakumar, M., 1966. Weed index: A new method for reporting weed control trials. Indian Journal of Agonomy 14(1), 96-98.

Hawaldar, S., Agasimani, C.A., 2012. Effect of herbicides on weed control and productivity of maize (Zea mays L.). Karnataka Journal of Agricultural Sciences 25 (1), 137-139.

Kashid, N.V., Barhate, K.K., Bodake, P.S., 2015. Management of weeds in direcd seeded rice. Indian Journal of Weed Science 47(2), 110-112.

Malik, R.K., Panwar, R.S., Bhan, V.M., 1988. Influence of methods of sowing and herbicides on weed control in wheat. Indian Journal of Weed Science 20(3), 20-25.

Mani, V.S., Malla, M.L., Gautam, K.C., Bhagwandas., 1973. Weed killing chemical in potato cultivation. Indian Fmg. (8), 17-18.

Patil, B., Reddy, V.C., 2014. Weed management practices in irrigated organic fingermillet (Eleusine coracana (L.) 
Gaertn.). Scholars Journal of Agriculture and Veterinary Sciences 1(4A), 211-215.

Patil, B., Reddy, V.C., Ramachandra Prasad, T.V., Shankaralingappa, B.C., Devendra, R., Kalyanamurthy, K.N., 2013. Weed management in irrigated organic fingermillet. Indian Journal of Weed Science 45(2), 143-145.

Pradhan, A., Rajput, A.S., Thakur, A., 2012. Effect of weed management practices on fingermillet under rainfed conditions. Indian Journal of Weed Science 44(2), 115-117.

Pradhan, A., Rajput, A.S., Thakur, A., 2010. Effect of weed management on growth and yield of fingermillet. Indian Journal of Weed Science 42(1\&2), 53-56.

Rahaman, S., Mukherjee, P.K., 2009. Effect of herbicides on weed-crop association in wheat. Journal of Crop and Weed 5(2), 113-116.

Ramesh, G., Nadanassababady, T., 2005, Impact of herbicides on weeds and soil ecosystem of rainfed maize (Zea mays L.). Indian Journal of Agricultural Research 39(1), 31-36.

Singh, P., Nepalia, V., Tomar, S.S., 2006. Effect of weed control and nutrient management on soybean productivity. Indian Journal of Agonomy 51(4), 314-317.

Sinha, A.K., Singh, R.P., 2005. Studied on the effect of herbicide under different tillage practices in wheat. Indian Journal of weed Science 37(3\&4), 159-162.

Tomar, G.S., Taunk, S.K., Choudhary, J.L., 2011. Science of crop production part-1 kharif crop. Kushal publication, Varanasi, India, 182-183.

Vinothini, G., Arthanari, P.M., 2017. Pre emergence herbicide application and hand weeding for effective weed management in irrigated kodo millet (Paspalum scrobiculatum L.). International Journal of Chemical Studies 5(3), 366-369. 